\title{
Hydrodeoxygenation and pyrolysis of free fatty acids obtained from waste rendering fat
}

Martyna Murat, Jaromír Lederer, Alena Rodová, José Miguel Hidalgo Herrador ${ }^{+}$[

Unipetrol Centre for Research and Education, a. s., Research Department, Revoluční 1521/84, 40001 Ústí nad Labem, Czech Republic

+Corresponding author: José Miguel Hidalgo Herrador, Phone: +420-731534973, Email address: jose.hidalgo@unicre.cz

\section{ARTICLE INFO}

Article history:

Received: October 1, 2019

Accepted: February 19, 2020

Published: July 1, 2020

\section{Keywords:}

1. animal fat

2. pyrolysis

3. hydrodeoxygenation

4. hydrotreatment

5. free fatty acids

\begin{abstract}
Non-edible fats are a common renewable feedstock for the biofuels production to avoid partially the use of edible feeds and fossil fuels. The aim of this work was the use of waste rendering fat to produce pyrolyzed and hydrogenated oils. The feedstock was hydrolyzed producing free fatty acids and glycerol + residues. The free fatty acids were pyrolyzed (with and without metal sulfides metal supported catalyst) or hydrotreated separately. An autoclave closed
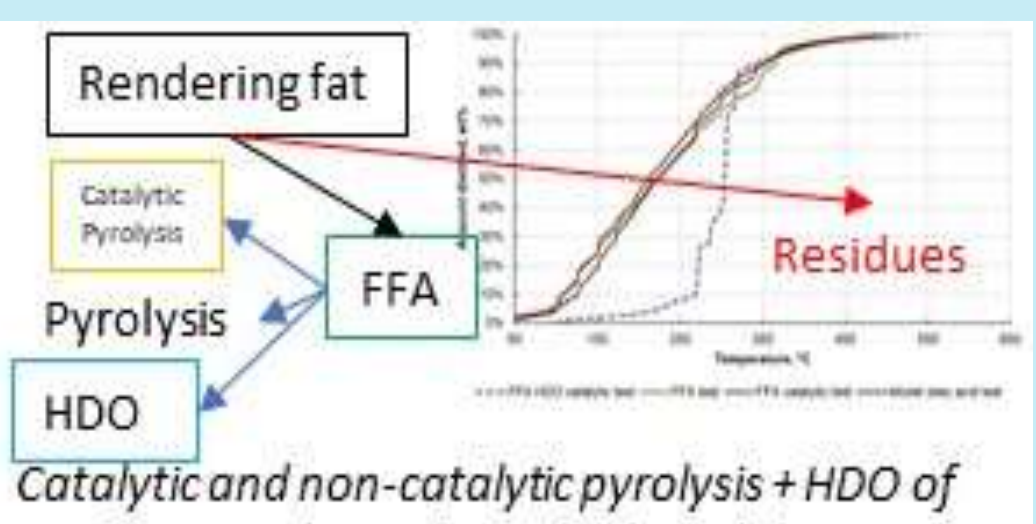
FFA from rendering fat to fuels and chemicals

hermetically in nitrogen (pyrolysis) or hydrogen (hydrotreatment) atmosphere was used. Gaseous products were analyzed by GC-FID/TCD. Liquid products were analyzed by Simulated Distillation (ASTM D2887) and FT-IR (attenuated total reflectance technique). For the pyrolysis, the main gaseous products were carbon dioxide, methane, ethane, and propane. For the hydrotreatment, the total amount of gases produced was much lower being the main product the carbon dioxide. For liquids, the hydrotreatment of the free fatty acids produced the respective hydrocarbons by decarboxylation reaction and the pyrolysis produced a mixture of compounds with lighter boiling ranges compared to the original free fatty acids. The use of a metal sulfide metal supported catalyst in the pyrolysis led to a higher amount of hydrogen production. but similar boiling range liquid products compared to the non-catalytic test.
\end{abstract}

\section{Introduction}

The petroleum location in unstable territories, the fossil fuel restrictions by law and the greenhouse carbon dioxide production led to a high need in biofuels production. Concretely, the revised Renewable Energy Directive (EU) 2018/2001, adopted in December 2018 by the European Parliament and by the Council of Ministers of the European Union, promotes the use of energy from renewable sources in the European Union. In addition, the European Union is avoiding the use of croplands for the biofuels production. In 2015 new rules came into effect to reduce the risk of indirect land use change (Renewable Energy Directive 2009/28/EC and the Fuel Quality Directive 2009/30/EC). Therefore, the use of wastes to produce biofuels can be considered as a necessary alternative for the biofuels production.

Three types of biofuels are considered worldwide: (i) first-generation biofuels (conventional ones such as fatty acids methyl esters - FAME), (ii) second-generation biofuels are produced from non-edible raw materials and can be 
produced by catalytic hydrotreatment and (iii) third-generation biofuels products from algae feedstock ${ }^{1}$. In the case of cold weather countries, the using of first-generation biofuels (biodiesel) can be a problem because they present a high freezing point or low energy density (due to its oxygen content). Second-generation biofuels are nowadays produced, in refineries, by catalytic hydro-processing to obtain hydrocarbons $s^{2-5}$. Particularly, non-edible feedstocks are being using in refineries ${ }^{6}$. Concretely, the use of waste animal fat $^{1,7}$ is considered as a good option for the biofuels production. Third-generation biofuels can be considered as a key technology. However, this technology needs to be still improved and implemented (not yet used on an industrial scale) ${ }^{8}$.

Rendering fat (RF) is a non-edible waste feedstock which can be produced from the waste of slaughterhouses and carcasses of livestock and it is considered as a cheap material for green diesel production ${ }^{9}$. However, RF contains usually high phosphorous and metal contents which could affect the catalytic activity ${ }^{9}$. RF is produced in Czech Republic in a relatively large amount so it can be considered as an available and cheap feedstock in this zone-area $^{10}$. The amount registered of rendering fat, sludge, meat and bone meals residues produced in Czech Republic (2018) were 36780 tons all together ${ }^{11}$. The lipid wastes generated by commercial enterprises in Czech Republic (2017) classified by groups were the next: Spent waxes and fats 1640 tons, waste fats and oils 21979 tons, edible fat, and oils 2971 tons and other greases and oil mixtures 374 tons $^{12}$.

Biofuels of second generation can be obtained by hydrodeoxygenation (HDO) or by pyrolysis. The pyrolysis is an extensively studied pathway to convert triacylglycerols to hydrocarbons. However, the study of pyrolysis for free fatty acids has received lower attention ${ }^{13,14}$. The aim of this work was to evaluate the free fatty acids (from rendering fat) processing by catalytic and noncatalytic pyrolysis to fuels and chemicals using metal sulfide supported catalyst and compare these results with standard hydrodeoxygenation (HDO) process by using the same catalyst. NiW sulfide supported on $\mathrm{SiO}_{2}-\mathrm{Al}_{2} \mathrm{O}_{3}$ is a commercial catalyst. This material was used instead standard NiMo or CoMo (used standardly for HDO reactions) supported catalysts with the added aim of cracking the free fatty acids to shorter molecules producing gases, gasoline and diesel fractions which could be then be evaluated for being used for fuels or petrochemistry.

\section{Experimental}

\subsection{Materials}

Waste RF (from dead animals, pig (80 wt.\%) also including chicken (14 wt.\%) and cow (6 wt.\%) residues) used in a previous work ${ }^{7}$ was analysed (metal and elemental C, H, N, S analyses) as shown in Tab. 1.

Table 1. Metals and elemental $\mathrm{C}, \mathrm{H}, \mathrm{N}, \mathrm{S}, \mathrm{O} \%$ (oxygen calculated by difference) and ash composition for the RF.

\begin{tabular}{|c|c|c|}
\hline Metal composition & Amount & Units \\
\hline $\mathrm{Al}$ & $<0.4$ & $\mathrm{mg} \mathrm{kg}^{-1}$ \\
\hline $\mathrm{Ca}$ & 110 & $\mathrm{mg} \mathrm{kg}^{-1}$ \\
\hline $\mathrm{Cr}$ & 6.38 & $\mathrm{mg} \mathrm{kg}^{-1}$ \\
\hline $\mathrm{Fe}$ & 13.3 & $\mathrm{mg} \mathrm{kg}^{-1}$ \\
\hline $\mathrm{K}$ & 218 & $\mathrm{mg} \mathrm{kg}^{-1}$ \\
\hline $\mathrm{Mg}$ & 16.6 & $\mathrm{mg} \mathrm{kg}^{-1}$ \\
\hline $\mathrm{Mn}$ & $<0.2$ & $\mathrm{mg} \mathrm{kg}^{-1}$ \\
\hline $\mathrm{Na}$ & 216 & $\mathrm{mg} \mathrm{kg}^{-1}$ \\
\hline $\mathrm{Ni}$ & $<0.2$ & $\mathrm{mg} \mathrm{kg}^{-1}$ \\
\hline $\mathrm{P}$ & 50.1 & $\mathrm{mg} \mathrm{kg}^{-1}$ \\
\hline $\mathrm{Ti}$ & $<0.2$ & $\mathrm{mg} \mathrm{kg}^{-1}$ \\
\hline $\mathrm{C}$ & 76.6 & wt. $\%$ \\
\hline $\mathrm{H}$ & 12.3 & wt. $\%$ \\
\hline S & -- & $\mathrm{mg} \mathrm{kg}^{-1}$ \\
\hline $\mathrm{N}$ & 800 & $\mathrm{mg} \mathrm{kg}^{-1}$ \\
\hline Oxygen by difference & 11.0 & wt. $\%$ \\
\hline Ash content ${ }^{1}$ & 0.3 & wt. $\%$ \\
\hline Acid value $^{2}$ & 65.5 & $\mathrm{mg} \mathrm{KOH} \mathrm{g}^{-1}$ \\
\hline Water content & 2650.3 & $\mathrm{mg} \mathrm{kg}^{-1}$ \\
\hline
\end{tabular}

${ }^{1}$ The ash content was calculated by TGA in Oxygen from 50 to $900{ }^{\circ} \mathrm{C}, 10{ }^{\circ} \mathrm{C} \mathrm{min}^{-1}$.

${ }^{2}$ Milligrams of $\mathrm{KOH}$ added to $1 \mathrm{~g}$ of $\mathrm{RF}$ to obtain $\mathrm{pH}=$ 7.

Oleic acid Lach-ner (Oleic acid min. 70\% pure/1000 ml; CAS: 67701-08-0; EINECS: 266932-7; Assay fatty acids (as oleic acid) min. 97\%; Refractive index 1.460 - 1.463) was used as model molecule for pyrolysis.

Dimethyl disulfide (DMDS) $\geq 99.0 \%$ Sigma Aldrich was used for the commercial catalyst sulfidation. $\mathrm{NiW} / \mathrm{SiO}_{2}-\mathrm{Al}_{2} \mathrm{O}_{3}$ reference material as 
catalyst with a 6.4 and $17.5 \mathrm{wt} . \%$ of $\mathrm{Ni}$ and $\mathrm{W}$ contents respectively $\left(200 \mathrm{~m}^{2} \mathrm{~g}^{-1}\right.$ of BET surface) was tested.

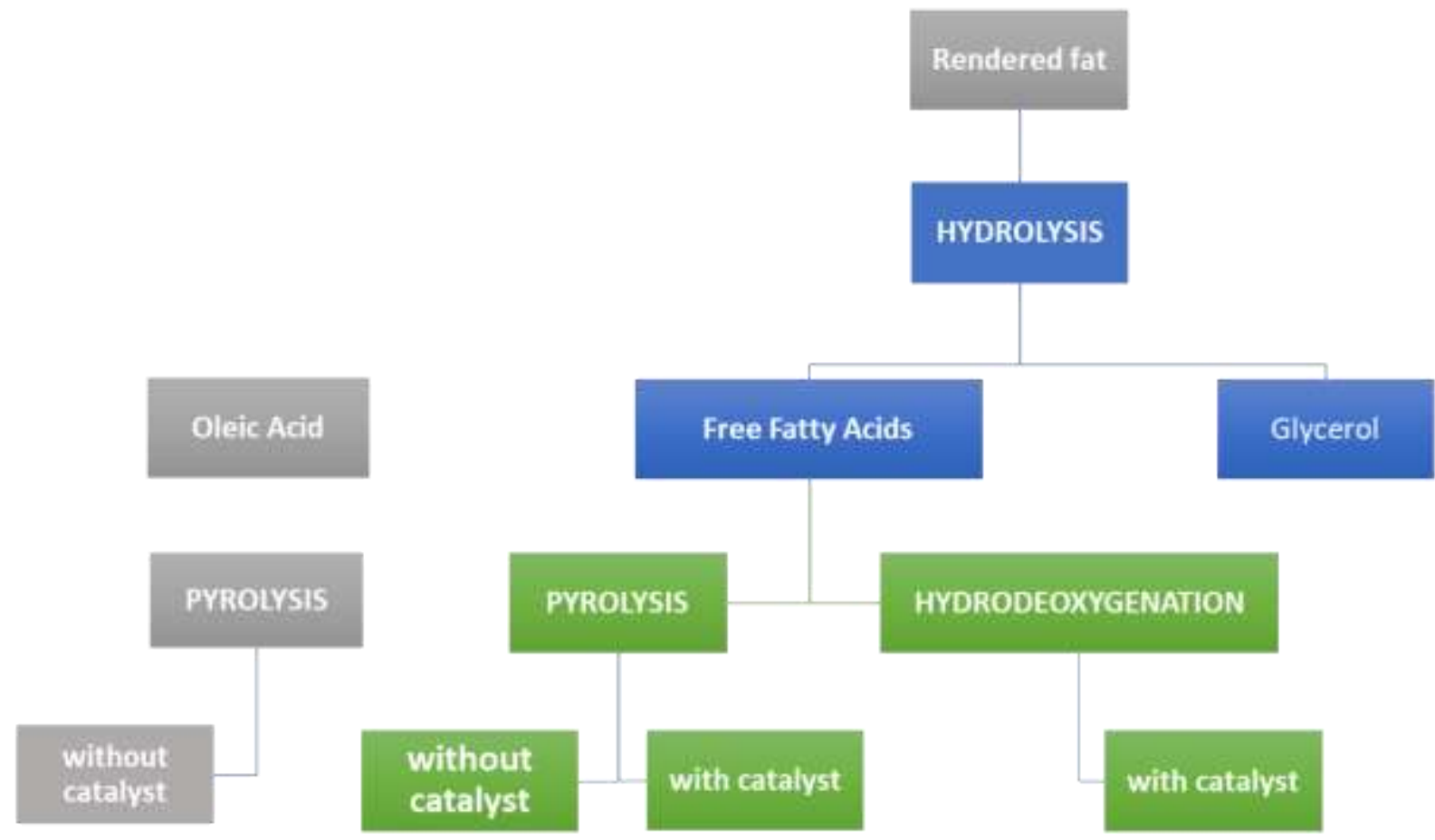

Figure 1. Scheme of the work-process using RF as feedstock for hydrolysis to FFA and then pyrolysis and HDO. Oleic acid was used as model molecule.

\subsection{Tests}

Experiments were performed in an autoclave 4575/76 with a "4848B" controller delivered by Parr Instruments Company. The scheme of the overall work-process is exposed in Fig. 1. The catalyst was activated using DMDS. $20 \mathrm{~g}$ of DMDS and $5 \mathrm{~g}$ of catalyst were used for each activation. DMDS and catalysts were introduced into the reactor-autoclave. Then, the reactor was flushed with nitrogen to remove air residues and finally flushed and pressurized to $5 \mathrm{MPa}$ with hydrogen. Temperature was then increased from ambient temperature $\left(24^{\circ} \mathrm{C}\right)$ to $340^{\circ} \mathrm{C}$ with a rate of $8.3{ }^{\circ} \mathrm{C}$ $\mathrm{min}^{-1}$. At this temperature $\left(340{ }^{\circ} \mathrm{C}\right)$, the pressure was increased to $15 \mathrm{MPa}$ (by $\mathrm{H}_{2}$ flow) and the reactor was kept at these conditions for $1 \mathrm{~h}$. The activation period was followed by the reactor external cooling by air flow (cooling rate approx. $4.5{ }^{\circ} \mathrm{C} \mathrm{min}^{-1}$ ) to ambient temperature and stabilization for $1 \mathrm{~h}$.
For hydrolysis of rendering fat, HDO and pyrolysis tests similar procedures were performed. Three types of tests were carried out:

A) For hydrolysis, two tests were performed, 50 $\mathrm{g}$ of rendering fat, $50 \mathrm{~g}$ of distilled water and $2 \mathrm{~g}$ of sulfuric acid were used. The reactor was under nitrogen atmosphere with no added pressure. Then, it was heated to $250{ }^{\circ} \mathrm{C}$ and maintained at this temperature during $1 \mathrm{~h}$ with $500 \mathrm{rpm}$ of stirring rate. After reaction, the system was externally cooled by air flow (approx. $4.5{ }^{\circ} \mathrm{C} \mathrm{min}^{-1}$ ) to room temperature and stabilized for $20 \mathrm{~h}$. After that, the liquid was collected for analysis. After the hydrolysis the glycerol was considered as side product while free fatty acids were further processed in two ways: in a pyrolysis or in HDO reaction.

B) For pyrolysis, $18.4 \mathrm{~g}$ of free fatty acids (FFA) and $3.7 \mathrm{~g}$ of activated-sulfide $\mathrm{NiW} / \mathrm{SiO}_{2}-$ $\mathrm{Al}_{2} \mathrm{O}_{3}$ catalyst were used. The autoclave was 
tested in nitrogen with no added pressure at room temperature and then heated to $420{ }^{\circ} \mathrm{C}$ with a heating rate of $8.3^{\circ} \mathrm{C} \mathrm{min}{ }^{-1}$. Reaction was conducted stirring with a rate of $500 \mathrm{rpm}$. Then, the system was externally cooled. Afterwards, the gas was sampled at $30^{\circ} \mathrm{C}$ and the autoclave depressurized. After that, the autoclave was opened, and the liquid collected for analysis. A blank probe, with $20 \mathrm{~g}$ of FFA and without the use of a catalyst and pyrolysis with oleic acid as a model molecule was also done, according to the above described procedure.

C) For HDO reaction, $20 \mathrm{~g}$ of FFA and $5 \mathrm{~g}$ of sulfide $\mathrm{NiW} / \mathrm{SiO}_{2}-\mathrm{Al}_{2} \mathrm{O}_{3}$ commercial catalyst were placed in the autoclave. The reactor was then flushed with nitrogen and pressurized with hydrogen to $7 \mathrm{MPa}$. Then, the reactor was heated up to $365{ }^{\circ} \mathrm{C}$. The system was maintained at $365^{\circ} \mathrm{C}$ for $1 \mathrm{~h}$ and stirred with $500 \mathrm{rpm}$. The, the system was cooled, and gas sampled at $30{ }^{\circ} \mathrm{C}$. Finally, the autoclave was depressurized and opened for collecting the liquid.

\subsection{Products analyses}

Liquid products of the reaction were characterized by simulated distillation (SimDist) using gas chromatography according to the ASTM D2887 and attenuated total reflectance FT-IR technique (ATR). Gaseous products were analysed by RGA-GC (Method Refinery Gas Analysis, Agilent).

\section{Results and Discussion}

First, the hydrolysis of the RF was performed. The hydrolysis of triglycerides (Triglyceride +3 $\mathrm{H}_{2} \mathrm{O} \rightleftharpoons 3$ Fatty Acids + Glycerol), in the presence of water, produces free fatty acids and glycerol (the sulfuric acid addition led to the acid hydrolysis). In this case, the hydrolysis reaction was carried out not only to produce free fatty acids and separate them from the glycerol but also to remove other possible water-soluble compounds included previously in the original rendering fat (not triglycerides).

Two tests with similar results (Tab. 2) were carried out. The simulated distillation of the FFA product presented about $90 \mathrm{wt} . \%$ of pure FFA (Fig. 2). After hydrolysis tests no gaseous samples (C1$\mathrm{C} 4$ gases) were produced. Glycerol and organic phases were separated by centrifugation. The organic phase SIMDIS is shown in Fig. 2.

The main products in the organic phase were FFA as shown in Fig. 2 (boiling range $340-420$ $\left.{ }^{\circ} \mathrm{C}\right)$. The SIMDIS was calibrated and as shown in a previous work ${ }^{7}$, the boiling range of $50-220{ }^{\circ} \mathrm{C}$ is related to $\mathrm{C} 5-\mathrm{C} 12$ compounds, $220-340{ }^{\circ} \mathrm{C}$ to $\mathrm{C} 12$ $\mathrm{C} 19,340-420{ }^{\circ} \mathrm{C}$ is mainly related to the free fatty acids but also to $\mathrm{C} 20+$ compounds and $>420{ }^{\circ} \mathrm{C}$ is related mainly to mono, di and triglycerides. Then, these FFA were used as feedstock for pyrolysis.

Table 2. Amount of liquid, gaseous and residue products obtained.

\begin{tabular}{|l|l|l|}
\hline Reaction & Liquid (wt.\%) & Gas (wt.\%) \\
\hline Hydrolysis of rendering fat 1. & 71.72 & 28.28 (no gases, residue) \\
\hline Hydrolysis of rendering fat 2. & 71.67 & 28.33 (no gases, residue) \\
\hline FFA test in nitrogen without catalyst & 64 & 36 \\
\hline FFA catalytic test in nitrogen & 79.64 & 20.36 \\
\hline Oleic acid test in nitrogen without catalyst & 82.5 & 17.5 \\
\hline Hydrodeoxygenation of FFA with catalyst & 94.8 & 5.2 \\
\hline
\end{tabular}




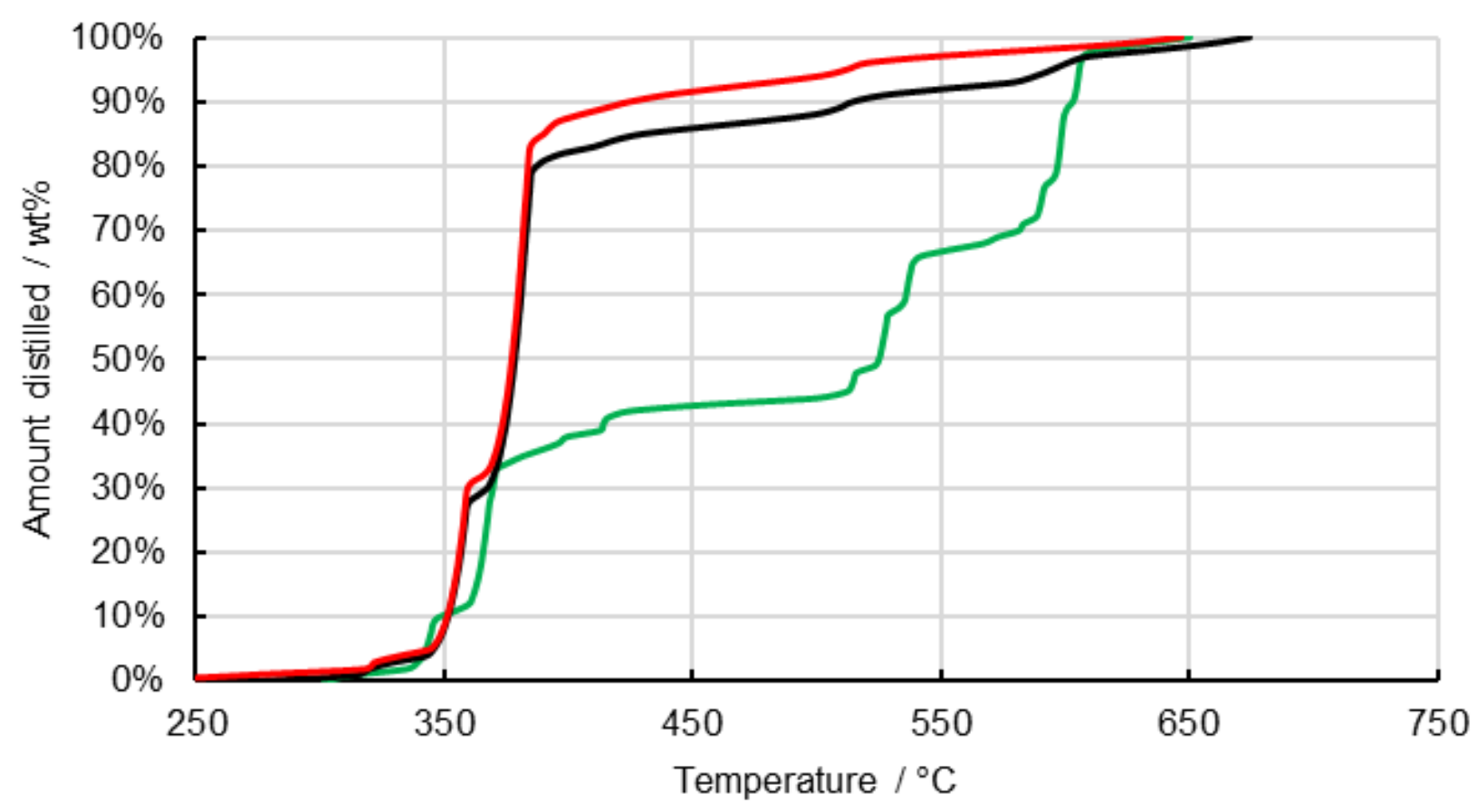

Rendered fat $\longrightarrow$ Rendered fat hydrolysis $1 \longrightarrow$ Rendered fat hydrolysis 2

Figure 2. Simulated distillation of rendering fat and hydrolysis products.

Next, after obtaining the FFA, two tests were carried out with FFA. One test using sulfide commercial catalyst and one test without catalyst. Oleic acid was also used as model molecule to perform a pyrolysis test for comparing results with those obtained using FFA from RF.

The pyrolysis led to an effective conversion to liquid and gaseous products different than feedstock as shown in Fig. 3. The SimDis and RGA analyses together demonstrated that the pyrolysis was effective producing lighter products compared to the free fatty acids (FFA) due to a cracking process. As shown in Tab. 2, the use of a sulfide catalyst increased the light liquid production and decreased the number of gaseous products C1-C6. The amount of gases and liquids compared between FFA and oleic acid tests are different due to the presence of other FFA in the animal fat (not only oleic acid). HDO test clearly led to hydrocarbons (Fig. 3) especially to products C15C18 according to calibrated RGA methodology peaks. This result is confirmed by ATR (Fig. 4) not showing signals for oxygenated compounds.

The gaseous products composition is shown in Fig. 5. The use of catalyst in nitrogen tests produced an increment in the hydrogen composition in gas products. Thus, the use of a sulfide catalyst led to a higher amount $\%$ of hydrogen in the product but a total less amount of gases as consequence of the higher production of carbon dioxide in nitrogen tests. In the case of the oleic acid, the amount\% composition is similar to the FFA test without catalyst in nitrogen. So, the gasification activity was similar in selectivity but different in the total production of gases. The total production of gases could be favored by the other compounds present in the animal fat.

HDO test clearly showed four main increments of the amount distilled at $270,286,305$ and $318^{\circ} \mathrm{C}$ which are related to $\mathrm{C} 15-\mathrm{C} 18$ hydrocarbons, respectively. Two significative increments of amount distilled were also shown for catalytic FFA pyrolysis tests (C15 and C17 hydrocarbons zone) indicating that the use of the metal sulfide catalyst led to a higher amount of C15, C17 hydrocarbons. However, in pyrolysis no hydrogen was used so these hydrocarbons could be produced by the hydrogen produced by the initial FFA hydrogen loss originated during the test. 


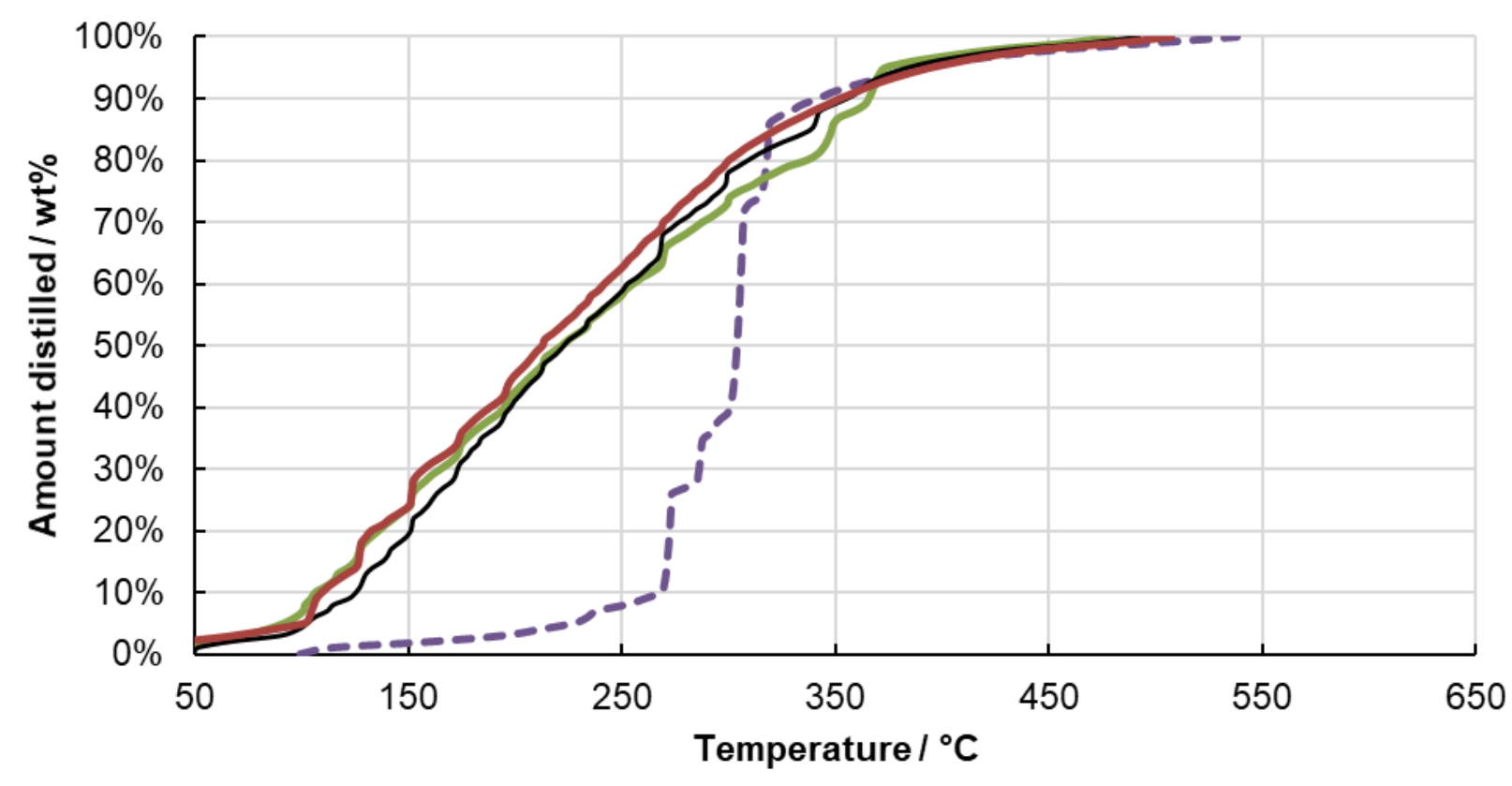

- - - FFA HDO catalytic test — FFA test

-FFA catalytic test Model oleic acid test

Figure 3. SimDis of liquid products from tests using nitrogen and for HDO test. The reaction was conducted without catalyst in nitrogen (FFA and Model oleic acid tests), with sulfide catalyst (FFA HDO catalytic test and FFA catalytic test).

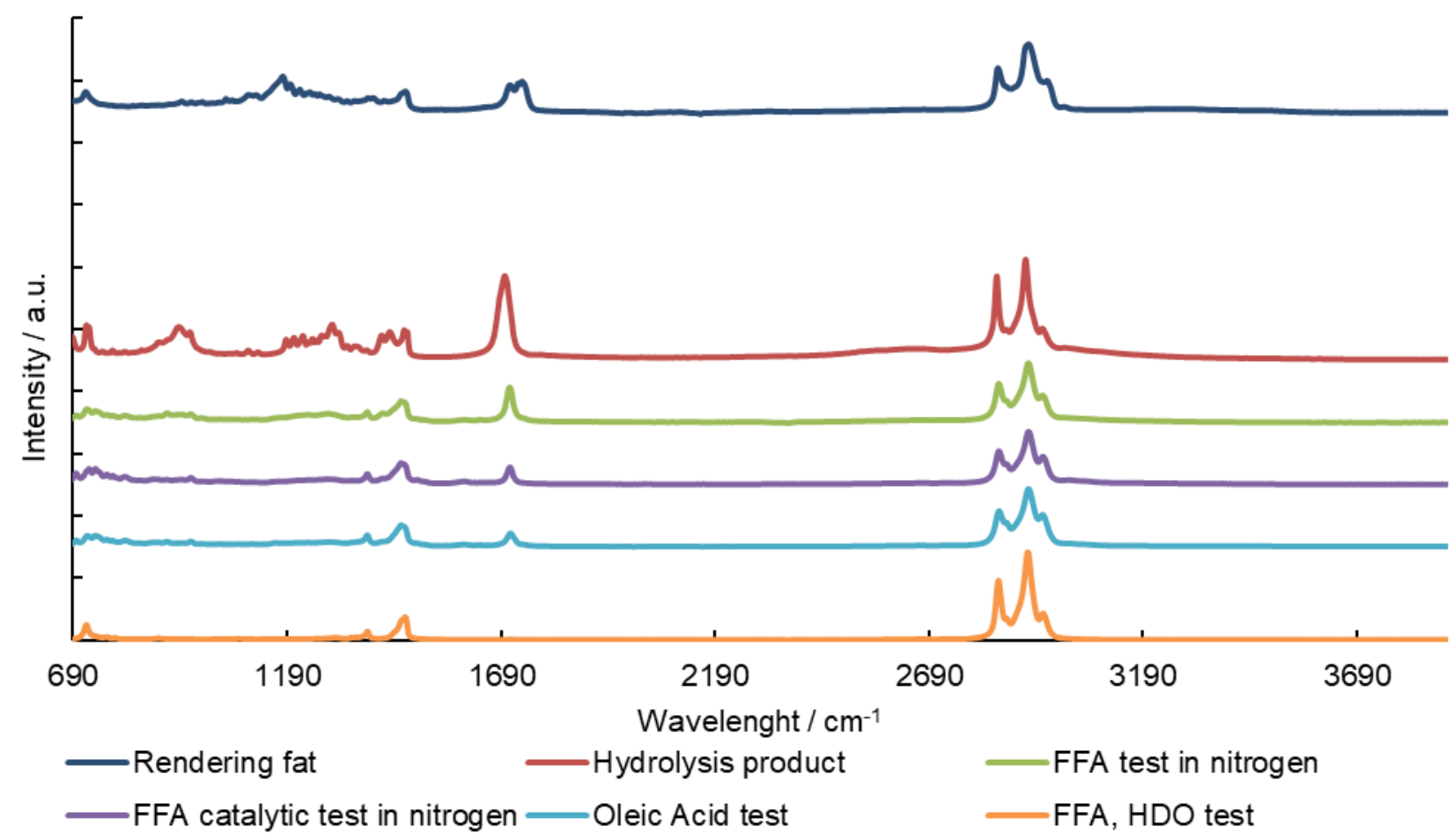

Figure 4. ATR spectrum of all feedstocks and reaction products in this experiment. 


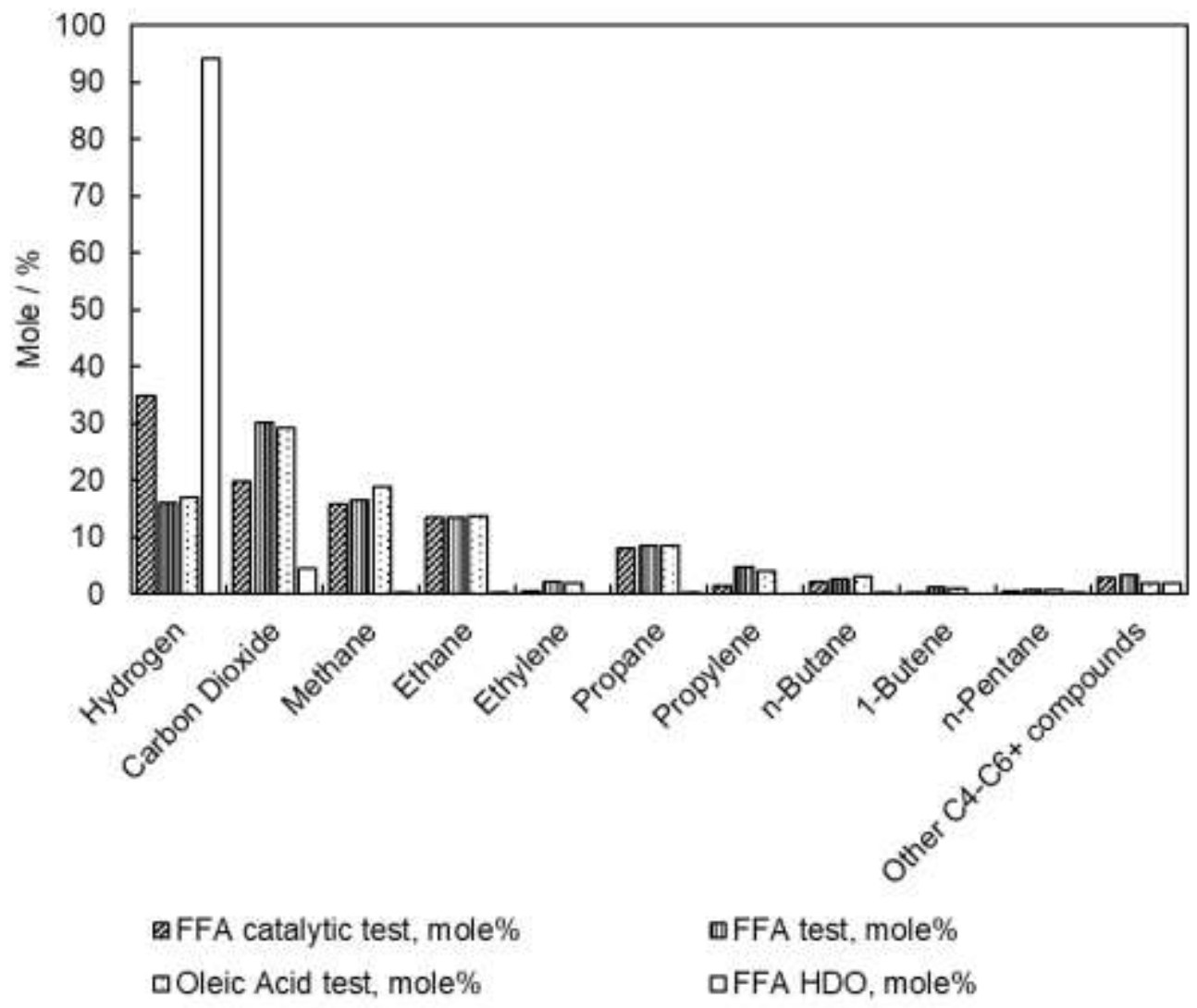

Figure 5. RGA gases analysis for pyrolysis and HDO tests.

ATR absorbance spectra of liquid products in the frequency range between 690 and $4000 \mathrm{~cm}^{-1}$ are shown in Fig. 5. In general, for triglycerides and hydrogenated vegetable oils, the bands at 2925 , $2965 \mathrm{~cm}^{-1}$ are related to the stretching vibrations of the $\mathrm{CH}_{3}$ and $\mathrm{CH}_{2}$ groups ${ }^{14}$. The absorption at $3100-3000 \mathrm{~cm}^{-1}, 1603 \mathrm{~cm}^{-1}, 1500 \mathrm{~cm}^{-1}$ and 900 $700 \mathrm{~cm}^{-1}$ is typical for aromatic compounds ${ }^{14}$. The band at $1709 \mathrm{~cm}^{-1}$ can be attributed to the presence of free fatty acids and the band at $1746 \mathrm{~cm}^{-1}$ to the ester carbonyl functional group of the triglycerides which was only present in the feedstock ${ }^{14}$. Concretely, the band at $1746 \mathrm{~cm}^{-1}$ was only found for the feedstock confirming the hydrolysis of the animal fat to FFA. However, for the feedstock and hydrolysis products, the band at $1182 \mathrm{~cm}^{-1}$ can be attributed to the stretching vibration of the $\mathrm{C}-\mathrm{O}$ ester groups indicating a non-complete hydrolysis being this result in agreement with SimDis (amounts distilled at higher temperatures than 420 $\left.{ }^{\circ} \mathrm{C}\right)$. At $727 \mathrm{~cm}^{-1}$ was found a band attributed to the overlapping of the $\mathrm{CH}_{2}$ rocking vibration and the out-of-plane vibration of cis-disubstituted olefins ${ }^{14}$. The shoulder at $2890-3009 \mathrm{~cm}^{-1} \mathrm{C}-\mathrm{H}$ (stretching vibration of the cis-double bond $(=\mathrm{CH})$ ) found for the feedstock was also present in the liquid products.

Although the pyrolysis and HDO reaction of oleic acid and rendering fat were already studied $^{15-18}$, to the best of our knowledge, comparing with literature, a comparison between non-catalytic and catalytic pyrolysis of renderingfat using sulfide catalyst was not found. In addition, the use of oleic acid led to know the possible differences by using real feedstock and this model molecule.

\section{Conclusions}

Several tests of hydrolysis, HDO and pyrolysis were performed obtaining good yields to free fatty acids (hydrolysis) and hydrocarbons (HDO). Pyrolysis tests of FFA were carried out with and without catalyst to see its influence. The use of catalyst led to an increment in hydrogen production, decrease in total gas production and to higher amounts of $\mathrm{C} 15$ and $\mathrm{C} 17$ hydrocarbons compared to non-catalytic pyrolysis. Lighter olefins, aromatics and hydrocarbons were produced after pyrolysis. 


\section{Acknowledgment}

This publication is a result of the project CACTU, Reg.

No. CZ.02.1.01/0.0/0.0/17_049/0008397, which has been co-financed by European Union from the European Regional Development Fund through the Operational Programme Research, Development and Education. This project has also been financially supported by the Ministry of Industry and Trade of the Czech Republic which has been providing institutional support for long-term conceptual development of research organization. The project CACTU has been integrated into the National Sustainability Programme I of the Ministry of Education, Youth and Sports of the Czech Republic (MEYS) through the project Development of the UniCRE Centre (LO1606). The result was achieved using the infrastructure of the project Efficient Use of Energy Resources Using Catalytic Processes (LM2015039) which has been financially supported by MEYS within the targeted support of large infrastructures.

\section{References}

[1] de Paz Carmona, H., de la Torre Alfaro, O., Alayón, A. B., Vázquez, M. A. R., Hernández, J. J. M., Coprocessing of straight run gas oil with used cooking oil and animal fats, Fuel 254 (2019) 115583. https://doi.org/10.1016/j.fuel.2019.05.166.

[2] Bezergianni, S., Dimitriadis, A., Kikhtyanin, O., Kubička, D., Refinery co-processing of renewable feeds, Progress in Energy and Combustion Science 68 (2018)

29-64.

https://doi.org/10.1016/j.pecs.2018.04.002.

[3] Kovács, S., Boda, L., Leveles, L., Thernesz, A., Hancsók, J., Catalytic hydrotreating of triglycerides for the production of bioparaffin mixture, Chemical Engineering Transactions 21 (2010) 1321-1326. https://doi.org/10.3303/CET1021221.

[4] Arun, N., Sharma, R. V., Dalai, A. K., Green diesel synthesis by hydrodeoxygenation of bio-based feedstocks: Strategies for catalyst design and development, Renewable and Sustainable Energy Reviews $\quad 48 \quad$ (2015) 240-255. https://doi.org/10.1016/j.rser.2015.03.074.

[5] Dujjanutat, P., Kaewkannetra, P., Production of biohydrogenated kerosene by catalytic hydrocracking from refined bleached deodorised palm/ palm kernel oils,
Renewable Energy $147 \quad$ (1) (2020) 464-472. https://doi.org/10.1016/j.renene.2019.09.015.

[6] Chrysikou, L. P., Dagonikou, V., Dimitriadis, A., Bezergianni, S., Waste cooking oils exploitation targeting EU 2020 diesel fuel production: Environmental and economic benefits, Journal of Cleaner Production 219 (2019) 566-575. https://doi.org/10.1016/j.jclepro.2019.01.211.

[7] Hidalgo, J. M., Tišler, Z., Vráblík, A., Velvarská, R., Lederer, J., Acid-modified phonolite and foamed zeolite as supports for NiW catalysts for deoxygenation of waste rendering fat, Reaction Kinetics, Mechanisms and $\begin{array}{lllll}\text { Catalysis } & 126 & \text { (2) } & \text { (2019) 773-793. }\end{array}$ https://doi.org/10.1007/s11144-018-1510-1.

[8] Correa, D. F., Beyer, H. L., Fargione, J. E., Hill, J. D., Possingham, H. P., Thomas-Hall, S. R., Schenk, P. M., Towards the implementation of sustainable biofuel production systems, Renewable and Sustainable Energy Reviews $\quad 107 \quad$ (2019) 250-263. https://doi.org/10.1016/j.rser.2019.03.005.

[9] Baladincz, P., Hancsók, J., Fuel from waste animal fats, Chemical Engineering Journal 282 (2015) 152-160. https://doi.org/10.1016/j.cej.2015.04.003.

[10] Višsek, L., Pokorný, M., Production of fatty acid esters (Biodiesel Oil) from waste animal fats, Chemicke Listy 107 (2013) 476-478.

[11] Statistics on the energy use of waste and alternative fuels (1989-2018), Results of statistical surveys. Ministry of Industry and Trade of the Czech Republic. Secondary energy sources Report, 2019 https://www.mpo.cz/cz/energetika/statistika/obnoviteln e-zdroje-energie/statistika-energetickeho-vyuzivaniodpadu-a-alternativnich-paliv-1989-_-2018--245185/.

[12] Generation, Recovery and Disposal of Waste 2017, Czech Statistical Office, 2018. https://www.czso.cz/csu/czso/generation-recovery-anddisposal-of-waste-2017.

[13] Toteva, V., Georgiev, A., Topalova, L., Oxidative desulphurization of light cycle oil: Monitoring by FTIR spectroscopy, Fuel Processing Technology 90 (7-8) (2009) 965-970. https://doi.org/10.1016/j.fuproc.2009.03.012.

[14] Vlachos, N., Skopelitis, Y., Psaroudaki, M., Konstantinidou, V., Chatzilazarou, A., Tegou, E., Applications of Fourier transform-infrared spectroscopy to edible oils, Analytica Chimica Acta 573-574 (2006) 459-465. https://doi.org/10.1016/j.aca.2006.05.034. 
[15] Leon, M., Garcia, A. N., Marcilla, A., MartinezCastellanos, I., Navarro, R., Catala, L., Thermochemical conversion of animal by-products and rendering products, Waste Management 73 (2018) 447-463. https://doi.org/10.1016/j.wasman.2017.08.010.

[16] Asomaning, J., Mussone, P., Bressler, D. C., Thermal deoxygenation and pyrolysis of oleic acid, Journal of Analytical and Applied Pyrolysis 105 (2014) 1-7. https://doi.org/10.1016/j.jaap.2013.09.005.

[17] Asomaning, J., Mussone, P., Bressler, D. C., Thermal cracking of free fatty acids in inert and light hydrocarbon gas atmospheres, Fuel 126 (2014) 250-255. https://doi.org/10.1016/j.fuel.2014.02.069.

[18] Asomaning, J., Mussone, P., Bressler, D. C., Pyrolysis of polyunsaturated fatty acids, Fuel Processing $\begin{array}{llll}\text { Technology } & 120 & \text { (2014) 89-95. }\end{array}$ https://doi.org/10.1016/j.fuproc.2013.12.007. 